\title{
Molecular Detection of Brucella Organism from Milk and Milk Products
}

\author{
Praveshika Dubey $^{2}$, Kirit B. Patel ${ }^{1}$, B.K. Patel ${ }^{1}$, H.C. Chauhan ${ }^{1}$, B.S. Chandel ${ }^{1}$, \\ S.S. Patel ${ }^{1}$, M.D. Shrimali ${ }^{1}$, J.K. Kala ${ }^{1}$, M.G. Patel ${ }^{1}$, A.C. Patel ${ }^{1}$, \\ Manish Rajgor ${ }^{1}$, M.A. Patel $^{1}$ and A.N. Modi ${ }^{1}$ \\ ${ }^{1}$ Department of Animal Biotechnology and Veterinary Microbiology, College of Veterinary \\ Science and Animal Husbandry, Sardarkrushinagar Dantiwada Agricultural University, \\ Sardarkrushinagar- 385 506, Gujarat, India \\ ${ }^{2}$ Department of Biotechnology, Hemchandracharya North Gujarat University, Patan, India \\ *Corresponding author
}

\begin{tabular}{|c|c|}
\hline & A B S T R A C T \\
\hline $\begin{array}{l}\text { Ke y w o r d s } \\
\text { Milk Ring Test } \\
\text { (MRT), Brucella, } \\
\text { DNA Extraction, } \\
\text { PCR, Milk product. }\end{array}$ & $\begin{array}{l}\text { Brucellosis is the most common zoonosis in the world, Brucellosis is an infectious disease } \\
\text { caused by bacteria of the genus Brucella. The disease has a considerable impact on human } \\
\text { and animal health, as well as socioeconomic impacts, especially in which rural income } \\
\text { relies largely on livestock breeding and dairy products. The disease can also be transmitted } \\
\text { by direct or indirect contact with infected animals. Humans are commonly infected } \\
\text { through ingestion of raw milk, milk product, meat or through direct contact with infected }\end{array}$ \\
\hline Article Info & $\begin{array}{l}\text { animals. In presence study was undertaken for the molecular detection of brucella } \\
\text { organism from milk and milk products from different places of Guiarat Out of } 85 \text { milk }\end{array}$ \\
\hline $\begin{array}{l}\text { Accepted: } \\
12 \text { March } 2017 \\
\text { Available Online: } \\
10 \text { April } 2017\end{array}$ & $\begin{array}{l}\text { samples, } 23(27.05 \%) \text { samples were found positive for Brucella antibodies by Milk Ring } \\
\text { Test (MRT). A total of } 168 \text { samples ( } 145 \text { milk product and } 23 \text { MRT positive milk samples) } \\
\text { processed for detection of Brucella organism using genus specific (B4/B5 primer) PCR. } \\
\text { Out of } 168 \text { samples, } 14 \text { samples amplicon at } 223 \mathrm{bp} \text { by Brucella genus specific }\end{array}$ \\
\hline
\end{tabular}

\section{Introduction}

Brucellosis is an important re-emerging zoonosis with a worldwide distribution. It is still an uncontrolled serious public health problem in many developing countries including India (Mantur et al., 2007). According to the food and Agriculture Organization (FAO), the World Health Organization (WHO) and the World Organization of Animal Health (OIE) brucellosis considered to be the most widespread zoonosis throughout the world (Mustafa, 1995). Brucellosis is an infectious disease caused by Gram negative, facultative, intracellular bacterial organisms of the genus
Brucella that is pathogenic for a wide variety of animals and human beings. It causes significant reproductive losses in sexually mature animals (Forbes, 1996; Wadood et al., 2009). The disease is manifested by late term abortions, weak calves, stillbirths, infertility and characterized mainly by placentitis, epididymitis and orchitis, with excretion of the organisms in uterine discharges and milk (England et al., 2004). The commonest source of Brucella infection is the dairy cow and the commonest mode of transmission is the ingestion of milk and milk product containing viable Brucella. Thus the identification of 
milk from infected cow is a matter of substantial public health importance.

Diagnosis of Brucellosis by cultural isolation, serology and nucleic acid amplification has been explored for the techniques. A number of nucleic acid sequences have been targeted for the development of Brucella genus specific PCR assays, including 16S rRNA (Romero et al., 1995), IS711 genetic element, omp2 (Leal-Klevezas et al., 1995) and bcsp31.

Rapid detection and confirmation of Brucella, the Brucellosis diagnosis, surveillance and screening by various serological tests, milk ring test is one of the most important screening test for detection of Brucella antibody from milk. Confirmatory diagnosis of brucellosis is by molecular level.

\section{Materials and Methods}

\section{Collection of samples}

A total of 230 samples of milk and milk products (cheese, paneer, curd, ice-cream, cream) were collected in a sterile container from various places of Gujarat (Table 1).

\section{Milk Ring Test (MRT) / Aborts Bang ring test (ABR)}

After thorough mixing $3 \mathrm{ml}$ milk samples were taken in a test tube. Add 3 drops of ABR antigen and gently mixed (ABR-antigen prepared byIAH and VB, Hebbal, Bangalore). The tubes were incubated at $37^{\circ} \mathrm{C}$ for one hour. Then keep at room temperature for 30 $\min$.

Blue colored ring of cream layer at the top and absence of color in milk layer is considered as a positive. If whole milk retains blue is considered as a negative.

\section{Molecular detection of Brucella}

\section{DNA extraction}

To make the suspension of milk product using homogenizer, DNA extraction was carried out from milk product (145) and MRT positive milk (23) samples using DNeasy Blood and Tissue Kit (Qiagen) following manufacturers protocols.

\section{Detection of Brucella using genus-specific B4/B5 primer}

A PCR was standardized in a total reaction volume of $25 \mu \mathrm{l}$, containing $12.5 \mu \mathrm{l}$ of $2 \mathrm{x}$ PCR Master mixture, 10 pmol of forward (5'TGG CTC GGT TGC CAA TAT CAA3') and reverse (5'CGC GCT TGC CTT TCA GGT CTG3') ${ }^{4}$ primers each 1 $\mu 1$, Template DNA $2 \mu 1$ and nuclease free water upto $25 \mu \mathrm{l}$. The reaction was standardized in a thermal cycler (Eppendorf, Germany). with initial denaturation at $93^{\circ} \mathrm{C}$ for $5 \mathrm{~min}$, followed by 35 cycles at $90^{\circ} \mathrm{C}$ for $60 \mathrm{~s}, 64^{\circ} \mathrm{C}$ for $30 \mathrm{~s}$ and $72^{\circ} \mathrm{C}$ for $60 \mathrm{~s}$. Final extension was carried out at $72^{\circ} \mathrm{C}$ for $10 \mathrm{~min}$. The amplified product (223bp) was electrophoresed in $2 \%$ agarose gel stained with ethidium bromide $(0.5 \mu \mathrm{g} / \mathrm{ml})$ and image was documented by gel documentation system (Mini BiS Bio Imaging System).

\section{Results and Discussion}

\section{Milk ring test}

Out of 85 milk samples, of these 23 (27.05\%) of samples were found positive for Brucella antibodies by MRT (Fig. 1). Present finding was in agreement with earlier studies which detected $25.21 \%$ Brucella antibody from milk by MRT (Zowghi et al., 1990). However, In contrast to the present findings, reported 9.16\% (Al-Mariri, 2015) and 56.32\% (Gulluce, 1996) Brucella antibody from milk by MRT. 
Table.1 Collection of samples from different places

\begin{tabular}{|c|c|c|c|c|c|c|c|}
\hline \multirow{2}{*}{$\begin{array}{l}\text { Sr. } \\
\text { No. }\end{array}$} & \multirow[t]{2}{*}{ Type of samples } & \multicolumn{5}{|c|}{ Places/Locations } & \multirow[t]{2}{*}{ Total } \\
\hline & & Local vendor & Deesa & Palanpur & Dantiwada & Patan & \\
\hline 1. & Milk & 45 & 10 & 10 & 10 & 10 & 85 \\
\hline 2. & Curd & 10 & 5 & 5 & 5 & 5 & 30 \\
\hline 3. & Cheese & -- & 5 & 5 & 5 & 5 & 20 \\
\hline 4. & Ice-cream & 5 & 10 & 10 & 10 & 10 & 45 \\
\hline 5. & Paneer & 5 & 5 & 5 & 5 & 5 & 25 \\
\hline 6. & Butter & 5 & 5 & 5 & 5 & 5 & 25 \\
\hline & Total & 70 & 40 & 40 & 40 & 40 & 230 \\
\hline
\end{tabular}

Fig.1 Milk ring test

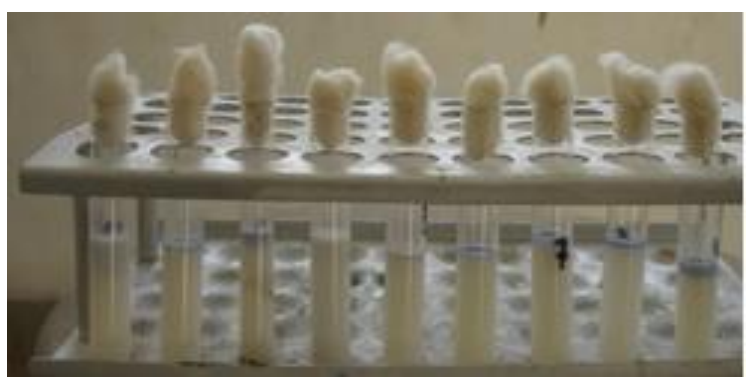

MRT Negative

MRT Positive

Fig.2 Genus specific PCR

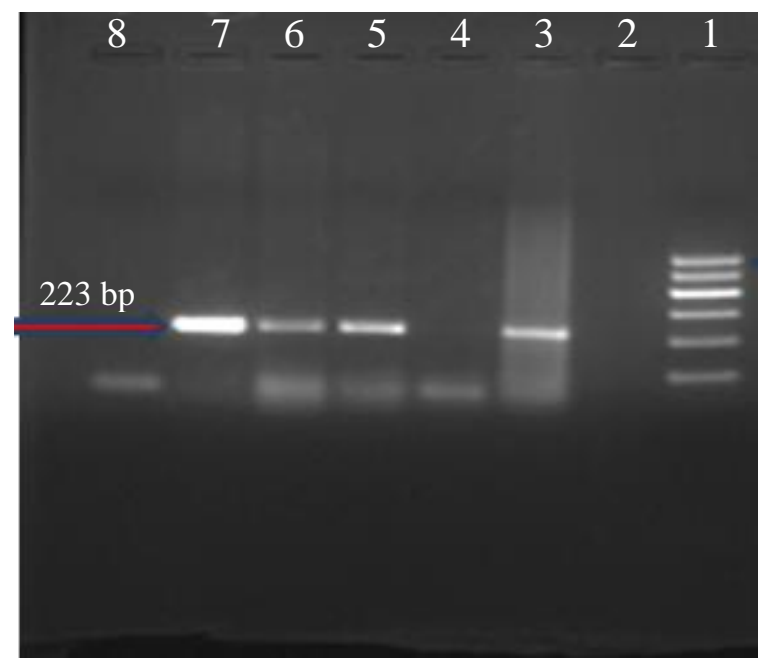

1-ladder

2-Negative control

3- Positive control 4- Sample (negative)

5-Sample (positive) 6- Sample (positive)

7- Sample (positive) 8- Sample (negative) 


\section{Molecular Detection of Brucella}

In PCR study targeting 16S rRNA gene, Out of 168 samples fourteen samples were found positive to give specific amplicon of $223 \mathrm{bp}$ region of the sequence encoding a $31 \mathrm{kDa}$ immunogenic bcsp31 by Brucella genus specific primer pairs B4/B5 (Fig. 2). Similarly, Kanani (2007) and Jung et al., (1998) detection of Brucella by using bcsp31 gene based B4/B5primer. Similarly, Ali (2014), Al-Mariri (2015) and Akbarmehr (2011) also detect Brucella organism from milk and milk products.

In conclusion, the detection of Brucella organism from milk of Brucella affected animal which is of public health importance because it is zoonotic disease. There is need to educate about how to prevent and control of brucellosis transmitted from animal to human by milk and milk product.

\section{Acknowledgement}

The authors are thankful to the Department of Animal Biotechnology and Veterinary Microbiology, College of Veterinary Science and A.H., SDAU, Sardarkrushinagar.

\section{References}

Akbarmehr, J. 2011. The prevalence of Brucella abortus and Brucella melitensis in local cheese produced in Sarab city, Iran and its public health implication. African J. Microbiol. Res., 5(12): 1500-1503.

Ali, A.N. 2014. Diagnosis of Brucella melitensis infection in goats milk by milk ring test and Polymerase chain reaction. Magazin of Al-Kufa Univ. for Biol., 6(1): 2073-8854.

Al-Mariri. 2015. Isolation of Brucella melitensis strains from Syrian bovine milk samples. Bulgarian J. Vet. Med., 18(1): 40.

Bailey, G.G., Krahn, J.B., Drasar, B.S., Stoker, N.G. 1992. Detection of Brucella melitensis and Brucella abortus by DNA amplification. J. Trop. Med. Hygiene, 95: 271-275.

England, L., Kelly, R.D., Jones, A., MacMillan, M., Wooldridge. 2004. A simulation model of brucellosis spread in British cattle under several testing regimes. Preventive Vet. Med., 63: 6373.

Forbes, L.B., Tessaro, S.V. 1996. Experimental Brucella abortus infection in wolves. J. Wildlife Dis., 40(1): 60-65.

Gulluce, M., Leloglu, N. 1996. Detection of Brucella abortus antibodies in cow milk of the Kars area by ELISA and MRT. Turkish J. Vet. Animal Sci., 20(4): 251255.

Jung, S.C., Jung B.Y., Woo, S.R., Cho, D.H., Kim, J.Y., Kim, W.T., Lee, J.M., Park, Y.H., Baek, B.K. 1998. Development of a PCR assay for the detection of Brucella spp. in bovine semen. Korean J. Vet. Res., 38: 345-352.

Kanani, A.N. 2007. Serological, cultural and molecular detection of Brucella infection in breeding bulls. Ph. D. thesis submitted to A. A. U., Anand.

Leal-Klevezas, D.S., Martinez, V.I.O., Lopez, M.A., Martinez, S.J.P. 1995. Single step PCR for detection of Brucella spp. from blood and milk of infected animals. $J$. Clin. Microbiol., 3: 3087-3090.

Mantur, B.G., Amarnath, S.K., Shinde, R.S. 2007. Review of clinical and laboratory features of human brucellosis. Indian J. Med. Microbiol., 25: 188-202.

Mustafa, A.H., Nicoletti, P. 1995. FAQ, WHO, OIE, guidelines for a regional brucellosis control programme for the Middle East workshop of Amman, Jordan, Ammenadad at the RoundTable. 
Romero, C., Pardo, M., Grillo, M.J., Diaz, R., Blasco, J.M., Lopez-Goni, I. 1995. Evaluation of PCR and indirect enzyme-linked immunosorbent assay on milk samples for diagnosis of brucellosis in dairy cattle. J. Clin. Microbiol., 33(12): 3198-3200.
Wadood, F., Ahmad, M., Khan, A., Gul, S.T., Rehman, N. 2009. Seroprevalence of brucellosis in horses in and around Faisalabad. Pak. Vet. J., 29: 196-198.

Zowghi, E., Ebadi, A., Mohseni, B. 1990. Isolation of Brucella organisms from the milk of seronegative cow. Rev. Sci. Tech. Off. Int. Epiz., 9(4): 1175-1178.

\section{How to cite this article:}

Praveshika Dubey, Kirit B. Patel, B.K. Patel, H.C. Chauhan, B.S. Chandel, S.S. Patel, M.D. Shrimali, J.K. Kala, M.G. Patel, A.C. Patel, Manish Rajgor, M.A. Patel and Modi, A.N. Molecular Detection of Brucella Organism from Milk and Milk Products. Int.J.Curr.Microbiol.App.Sci. 6(4): 1087-1091. doi: https://doi.org/10.20546/ijcmas.2017.604.135 